\title{
Exploring drought tolerance in coffee: a physiological approach with some insights for plant breeding
}

\author{
Fábio Murilo DaMatta
}

Departamento de Biologia Vegetal, Universidade Federal de Viçosa, CEP 36570-000 Viçosa, MG, Brasil.E-mail: fdamatta@ufv.br Received: 20/03/2004, Accepted:03/04/2004

This paper briefly reviews some selected traits (leaf area, crown architecture, water-use efficiency and carbon isotope discrimination, water relations and root characteristics), which may be explored in breeding programmes to tolerance to drought stress in arabica and robusta coffee.

Key words: Coffea, water deficit, water use, yield.

Explorando a tolerância à seca em café: uma abordagem fisiológica com algumas contribuições para o melhoramento vegetal: Nesta revisão, analisam-se brevemente algumas características (área foliar, arquitetura da copa, eficiência do uso da água e discriminação isotópica do carbono, relações hídricas e características radiculares) que podem ser exploradas em programas de melhoramento para tolerância à seca em cafeeiros arábica e robusta.

Palavras-chave: Coffea, déficit hídrico, produção, uso da água.

\section{INTRODUCTION}

Coffee is one of the most important commodities in the international agricultural trade, representing a significant source of income to several Latin American, African and Asian countries. Currently, Coffea arabica L. (arabica coffee) accounts for about $65 \%$ of the coffee produced, and $C$. canephora Pierre (robusta coffee) for the rest. In Brazil, the world's largest coffee producer, total coffee yield was about 48,500 million bags ( $60 \mathrm{~kg}$ ) of green beans in 2002/2003 ( $\mathrm{ca}$. $41 \%$ of the world production). It is predicted to decrease to around 28,000 million bags in 2003/2004 due largely to unfavourable climatic conditions, particularly limited water supply. Not only in Brazil but also in several coffee growing countries drought is considered to be the major environmental stress affecting coffee production.

The physiology of plant responses to drought stress is rather complex, showing different modifications following soil drying. The dynamics of soil water depletion, changes in water demand from the atmosphere, as well as plant growth and the phenological state in which water deficit is developed, are sources of the wide variation in plant responses to drought (Medrano et al., 1998). Furthermore, particularly in the tropics, drought episodes are remarkably aggravated by both high solar radiation and temperature, so drought should be accounted for as a multidimensional stress (DaMatta, 2003).

There was not a great deal of attention given to separating productivity under drought, which is important for agricultural plants, from survival mechanisms. Yet many adaptations to survival tend to reduce economic yield (Richards, 1997). As discussed by Mullet and Whitsitt (1997), one approach to improve crop performance in water-limited environments is to select for genotypes that have improved yield in these environments. This approach has proved partially successful, but difficult to accomplish due to the variability of rainfall and the polygenic nature of drought tolerance. A complementary approach to improve plant performance for drought-prone regions involves the identification and selection of traits that contribute to drought tolerance or wateruse efficiency (WUE). A partial list of potentially important traits might include water-extraction efficiency, WUE, hydraulic conductance, osmotic and elastic adjustments, and modulation of leaf area. Most of these traits are complex and their control and molecular basis are ill-understood. 
This review briefly discusses selected physiological and morphological traits of arabica and robusta coffee, which may be associated with tolerance to drought stress, with some implication for plant breeding.

Unless otherwise stated, information dealing with robusta concerns the variety 'Kouillou', known in Brazil as 'Conilon'.

\section{Leaf area and gas exchange}

In the short-term soil water deficit, yield reduction may be related to reduced stomatal conductance $\left(g_{\mathrm{s}}\right)$ and concomitantly lower rate of net carbon assimilation $(A)$. However, in most cases and particularly under prolonged drought stress, a smaller leaf area and an altered assimilate partitioning among the tree organs seem to be more directly responsible for decreased crop yield (DaMatta, 2003). In potgrown arabica coffee after 120 days under differential irrigation schemes, the total leaf area of trees irrigated twice weekly was halved in relation to those irrigated twice daily, although $A$ on a leaf area basis remained approximately constant (Meinzer et al., 1992). In addition to producing fewer leaves, plants irrigated twice weekly also showed higher rates of leaf senescence and produced considerably smaller leaves than plants irrigated twice daily. This pattern suggests that a major mode of adjustment to reduced soil water availability in arabica coffee, at least in early stages of soil water shortage, would consist in the maintenance of nearly constant $A$ on an area basis through a reduction in the rate of increase in total leaf area per plant (Meinzer et al., 1992). Similar results were also reported for field-grown robusta coffee (DaMatta et al., 2000, 2003). Thus, interpretation of short-term gas exchange measurements in leaves with this form of phenotypic adjustment to resource limitation may be problematic if the total leaf area is not considered. Even if it is considered, shortterm gas exchange measurements may not reveal differences in total carbon assimilation at the canopy level since the current gas exchange characteristics of a particular leaf may deviate considerably from those of the other leaves (Meinzer et al., 1992). One must be cautious, therefore, when screening coffee genotypes by measuring their instantaneous gas exchange under drought stress conditions.

In field-grown clones of robusta coffee, leaf shedding in response to drought stress occurs sequentially from older to younger leaves; the more drought-sensitive the clone is, the greater the extent of leaf shedding (DaMatta and Rena, 2001). Apparently, this is not associated with oxidative stress since the extent of lipid peroxidation was similar in both irrigated and severely drought-stressed clones (predawn water potential lower than -4.0 MPa) (H.A. Pinheiro and F.M. DaMatta, unpublished results). Leaf abscission may be considered as a whole-plant mechanism to limit transpiration, but at least in robusta coffee senescence might be merely a consequence of, and not a defence against, stress since the drought-sensitive clones, which considerably lose their foliage, also show the most impaired water status in the remaining leaves.

\section{Crown architecture}

Stomatal control on transpiration may decrease substantially as the scale increases from leaf to canopy. As the leaf transpires, water vapour tends to humidify the air nearby the leaves, thus decreasing the boundary layer conductance surrounding each leaf and uncoupling the vapour pressure at the leaf surface from that of the bulk air. Tausend et al. (2000b), working with three arabica coffee cultivars with contrasting shoot morphologies, showed that regulation of transpiration was governed by divergent hydraulic architecture rather than stomatal physiology. Maximum total transpiration per plant, on a daily basis, was $13 \mathrm{~kg}$ in cv. Typica (conical, relatively open crown with $22.9 \pm 1,7 \mathrm{~m}^{2}$ leaf area), against $8 \mathrm{~kg}$ in cv. Yellow Caturra (flat top, dense crown with $27.5 \pm 3.3 \mathrm{~m}^{2}$ leaf area). This corroborates some empirical observation that dwarf cultivars with dense crowns (lower boundary layer conductance) are better able to postpone dehydration than cultivars with open crowns, regardless, within given limits, of their leaf areas. At least partially, these findings lend some support for explaining why the use of cultivars with open crowns, even if irrigation is supplemented, often results in crop failure in regions with high evaporative demand, as in north-eastern Brazil (DaMatta, 2004). Therefore, selection of cultivars for drought-prone environments should consider aspects concerning crown architecture.

\section{Carbon isotope discrimination}

Measurements of the stable carbon isotope discrimination $(\Delta)$ of leaf dry matter can provide a useful long-term indicator of WUE (Farquhar et al., 1989). As both diffusion and carboxylation of ${ }^{13} \mathrm{CO}_{2}$ are slower than those of ${ }^{12} \mathrm{CO}_{2}$, a higher proportion of ${ }^{12} \mathrm{C}$ is to be expected in plant tissues relative to that occurring in the ambient air. Since $\Delta$ is strongly correlated with the ratio of internal to ambient $\mathrm{CO}_{2}$ concentration (Farquhar et al. 1989), it should be then affected by both $g_{\mathrm{s}}$ and $A$ during the period of growth of individual leaves, and these are in turn influenced by environmental, morphological and physiological variables. There apparently 
is a large genetic variability in $\Delta$, it has a high repeatability and low genotype $\mathrm{x}$ environment interaction, thus making $\Delta$ very attractive when breeding for high WUE (Richards, 1997). In evergreen woody species, however, leaf $\Delta$ integrates phenological rhythms in gas exchange as well as changing environmental conditions. Therefore, restriction of sampling to upper sun leaves, as is often done, may produce results that do not reflect the behaviour of the canopy as a whole (Gutiérrez and Meinzer, 1994).

There is a considerable genetic variation in $\Delta$ in both arabica and robusta coffee (Meinzer et al., 1990a; DaMatta et al., 2000, 2003). Working with five genotypes of arabica, Meinzer et al. (1990a) pointed out that a higher long-term WUE (lower $\Delta$ ) under adequate irrigation resulted from decreased $g_{\mathrm{s}}$ rather than increased $A$ at a given $g_{\mathrm{s}}$. They also showed that genotypes with higher $\Delta$ under full irrigation had greater soil-to-leaf hydraulic conductance, depleting soil water more rapidly and experiencing symptoms of physiological stress earlier when water was withheld, thus indicating that $\Delta$ of well-watered coffee plants could be used to predict genotype performance under drought stress. This is of particular interest since a positive correlation between $\Delta$ and crop yield has been shown in arabica coffee (Meinzer et al., 1991). Nonetheless, this means that low $\Delta$ would be related to low productivity in wet environments on the one hand, and to some stability of coffee yield in drought-prone environments on the other hand.

\section{Water relations}

Water relations of coffee have been studied by several investigators over the last decades, and some reviews have been published on the subject (e.g., Nunes, 1976; Carr, 2001; DaMatta and Rena, 2001, 2002).

Osmotic adjustment (OA), defined as a net increased solute concentration, may be perceived as an important survival mechanism to drought stress (Turner, 1997), in addition to being frequently correlated with yield stability in dry environments (Blum, 1997). In both arabica and robusta coffee grown in the field, $\mathrm{OA}$ is not a general trait observed in genotypes grown under rainfed conditions (Meinzer et al., 1990b; DaMatta et al., 2003). In genotypes showing some $\mathrm{OA}$, its magnitude generally is smaller than $0.3 \mathrm{MPa}$ under full turgor, and seldom larger than 0.5 MPa. Furthermore, development of increased leaf water deficits upon discontinuing irrigation may circumstantially be more rapid (or severe) in genotypes having greater amplitude of OA (Meinzer et al., 1990b; DaMatta et al., 1993). These observations imply that OA may not be an effective mechanism of drought tolerance in coffee, as has also been reported for several other woody species (Fan et al., 1994).

In some species, accumulation of compatible solutes, such as proline and quaternary ammonium compounds, has been considered as an adaptation to drought stress. In coffee, however, such accumulation does not satisfactorily correlate with drought tolerance in various cultivars of arabica and robusta. In any case, a build-up of those compounds under water deficit conditions appears to be a sensitive indicator of leaf water status (Maestri et al., 1995). According to Mazzafera and Teixeira (1989), proline accumulation in drought-stressed plants of arabica coffee might be more directly related to injury imposed by water limitation rather than being a defence mechanism against drought stress.

Coffee retains a high leaf relative water content (RWC) under dehydrating conditions, being considered a watersaving rather than a dehydrating tolerant species (Nunes, 1976; Josis et al., 1983; DaMatta et al., 1993). This may be attributed to (i) an efficient stomatal control on transpiration (Nunes and Duarte, 1969; Nunes, 1976; Josis et al., 1983; Meguro and Magalhães, 1983; Pinheiro, 2004), and/or (ii) low cell-wall elasticity (Meinzer et al., 1990b; DaMatta et al., 1993, 2002, 2003; Pinheiro, 2004). A small water loss should therefore cause a shift in turgor so that leaves tend to maintain a high RWC to retain a high symplast volume. Thus it appears that under water deficit the maintenance of a high RWC is more important than OA per se in conferring drought tolerance to the coffee plant (DaMatta et al., 1993). Conservation of a high symplast volume may be crucial for maintaining gas exchange, as shown by Meinzer et al. (1990b) working with five arabica coffee cultivars subjected to drought. They showed that $g_{\mathrm{s}}$ was associated with changes in relative symplast volume rather than with changes in leaf turgor. In any case, there does not appear to be differential ability among arabica coffee cultivars to modify the symplast volume-water potential relationship via osmotic and elastic adjustments.

In arabica coffee, $g_{\mathrm{s}}$ has been reported to be an early indicator of water shortage, showing decreases as soon as one-third of the available soil water has been depleted (Nunes, 1976). Also, $g_{\mathrm{s}}$ declines sharply with increasing evaporative demand irrespective of the leaf water status (Gutiérrez et al., 1994; Kanechi et al., 1995; Barros et al., 1997; Tausend et al., 2000a). By contrast, robusta coffee appears to exhibit a poorer stomatal control on transpiration than arabica (DaMatta et al., 1997). There is circumstantial evidence that control of 
stomatal aperture in cv. Apoatã (C. canephora var. robusta) by chemical signals from roots is less responsive to decreasing soil water availability than in arabica (Fahl et al., 2001). Robusta thrives in a typical equatorial climate (abundant rainfall distributed over a nine to ten month period and relative humidity approaching saturation), whereas arabica coffee evolved in a region marked by a relative dry season lasting about four to five months together with a relatively lower atmospheric humidity (Willson, 1999). The requirement for an efficient stomatal control on transpiration would not therefore be as imperative for robusta as for arabica coffee. However, such simplifications are somewhat adventurous considering the wide polymorphism that exists, particularly within robusta. Whatever the case, under plantation conditions stomatal limitations to photosynthesis seem to be more important in arabica than in robusta coffee, although survival of arabica may be enhanced under prolonged droughts (DaMatta and Rena, 2001). This has been further highlighted elsewhere (DaMatta, 2004).

In arabica coffee, hydraulic conductance was found to be positively correlated with total daily transpiration (Tausend et al., 2000a). Thus genotypes with higher hydraulic conductance should have higher rates of water use. This means that they may deplete accessible soil water more rapidly and/ or have a deeper root system than genotypes with lower hydraulic conductance. The strong association of total transpiration with hydraulic conductance might dampen variation in water potential with variation in water availability, which may help to avoid non-stomatal limitation to photosynthesis and xylem cavitation (Tausend et al., 2000a). This would be advantageous with non-limiting soil water or with brief periods of water deficit, but disadvantageous with longer-term drought since a high hydraulic conductivity would hasten the development of severe plant water deficit. Hence, knowledge of the nature of the target environment to which cultivars should be bred is crucial for the success of coffee breeding programmes.

\section{Root characteristics}

Drought-adapted plants are often characterised by deep and vigorous root systems. In robusta coffee, by growing four contrasting clones in large containers (120 L), Pinheiro et al. (2004) observed that a deeper root system could be associated with better avoidance to soil water limitation in droughttolerant clones than in drought-sensitive ones. Another study has associated drought tolerance with a larger root dry mass, shown by Ramos and Carvalho (1997) working with 29 coffee genotypes. These authors did not find significant genotypic correlations between drought tolerance and production, hence suggesting that these traits were independent of each other. A great limitation of this work resides in assessing the root system using seedlings and, by contrast, assessing production in field-grown adult plants. Moreover, it is not known if the root behaviour at the seedling stage resembles that of the adult coffee tree. In any case, the difficulties in evaluating root systems, the large environmental influences and the complex inheritance of root characteristics hinder the use of these traits in selection programmes in spite of the obvious positive relationship between root depth, root growth and yield under drought conditions (Medrano et al., 1998).

\section{CONCLUDING REMARKS}

To date, much research on drought tolerance in coffee has been conducted using pot-grown seedlings under greenhouse conditions. This approach has only a limited agronomic relevance since: (i) it is difficult to simulate in small volumes of soil the natural development of drought down a root profile; (ii) some responses to drought stress are hardly manifested, e.g. leaf rolling which is often observed in robusta coffee grown in the field but seldom observed when grown in greenhouses with limited irradiance; and (iii) adaptations to drought stress may not be resolved at a young developmental stage. In addition, traits such as leaf orientation, leaf rolling, thickness and composition of cuticle, and leaf surface reflectance, which may contribute both to decrease transpiration and to avoid photo-inhibitory damage and excessive leaf temperature, have not been explored. The use of molecular tools for studying drought tolerance has also not yet been a major goal in coffee, but it is currently in course in some laboratories.

A major component of differential adaptation to drought among arabica and robusta coffee genotypes appears to be behavioural, and may be governed by rates of water use or efficiency of extraction of soil water (Meinzer et al., 1990b; DaMatta et al., 2003; Pinheiro, 2004). Therefore, physiological and morphological characteristics, such as, $g_{\mathrm{s}}$, crown architecture, root depth and WUE, should be recommended as potential traits for selecting coffee genotypes with superior performance under drought conditions. In spite of Mazzafera and Carvalho (1987) pointing out that in some cases coffee yield and drought tolerance under field conditions may be independent of each other, potential yield may be negatively associated with certain drought-adaptive traits, as appears to be the case of $\Delta$ (Meinzer et al., 1991). Nonetheless, under 
low-input conditions typical of many farming systems of drought-prone regions, cultivars with better yield stability under drought stress, or better able to survive drought episodes, may be of greater value than cultivars with high potential yield selected for improved environments.

Acknowledgements: Thanks are due to the National Council for Scientific and Technological Development (CNPq, Brazil) and to the Brazilian Consortium for Coffee Research and Development for the fellowships held by the author during the preparation of this manuscript.

\section{REFERENCES}

Barros RS, Mota JWS, DaMatta FM, Maestri M (1997) Decline of vegetative growth in Coffea arabica L. in relation to leaf temperature, water potential and stomatal conductance. Field Crops Res. 54:65-72.

Blum A (1997) Crop responses to drought and the interpretation of adaptation. In: Belhassen E (ed), Drought Tolerance in Higher Plants: Genetical, Physiological and Molecular Biological Analysis, pp.57-70. Kluwer Academic Publishers, Dordrecht, The Netherlands.

Carr MKV (2001) The water relations and irrigation requirements of coffee. Exp. Agric. 37:1-36.

DaMatta FM (2003) Drought as a multidimensional stress affecting photosynthesis in tropical tree crops. In: Hemantaranjan A (ed), Advances in Plant Physiology, vol. 5, pp.227-265. Scientific Publishers, Jodhpur.

DaMatta FM (2004) Ecophysiological constraints on the production of shaded and unshaded coffee: a review. Field Crops Res. 86:99-114.

DaMatta FM, Chaves ARM, Pinheiro HA, Ducatti C, Loureiro ME (2003) Drought tolerance of two field-grown clones of Coffea canephora. Plant Sci. 164:111-117.

DaMatta FM, Loos RA, Silva EA, Ducatti C, Loureiro ME (2002) Effects of soil water deficit and nitrogen nutrition on water relations and photosynthesis of pot-grown Coffea canephora Pierre. Trees - Struct. Funct. 16:555-558.

DaMatta FM, Maestri M, Barros RS (1997) Photosynthetic performance of two coffee species under drought. Photosynthetica 34:257-264.

DaMatta FM, Maestri M, Barros RS, Regazzi A J (1993) Water relations of coffee leaves (Coffea arabica and C. canephora) in response to drought. J. Hort. Sci. 68:741746.

DaMatta FM, Rena AB (2001) Tolerância do café à seca. In: Zambolin L (ed), Tecnologias de Produção de Café com Qualidade, pp.65-100. Universidade Federal de Viçosa, Viçosa.

DaMatta FM, Rena AB (2002) Relações hídricas no cafeeiro. In: Encarnação RO, Afonso Jr PC, Rufino JLS (eds), I Simpósio de Pesquisa dos Cafés do Brasil: Palestras, pp.944. Embrapa Café, Brasília.
DaMatta FM, Silveira JSM, Ducatti C, Loureiro ME (2000) Eficiência do uso da água e tolerância à seca em Coffea canephora. In: Expanded Abstracts of the I Simpósio de Pesquisa dos Cafés do Brasil. Embrapa Café, Brasília, pp.907-910.

Fahl JI, Carelli MLC, Menezes HC, Gallo PB, Trivelin PCO (2001) Gas exchange, growth, yield and beverage quality of Coffea arabica cultivars grafted on to C. canephora and C. congensis. Exp. Agric. 37:241-252.

Fan S, Blake TJ, Blumwald E (1994) The relative contribution of elastic and osmotic adjustment to turgor maintenance of woody plants. Physiol. Plant. 90:414-419.

Farquhar GD, Ehleringer JR, Hubick KT (1989) Carbon isotope discrimination and photosynthesis. Annu. Rev. Plant Physiol. Plant Mol. Biol. 40:503-537.

Gutiérrez MV, Meinzer FC (1994) Estimating water use and irrigation requirements of coffee in Hawaii. J. Am. Soc. Hort. Sci. 119:652-657.

Gutiérrez MV, Meinzer FC, Grantz DA (1994) Regulation of transpiration in coffee hedgerows: Covariation of environmental variables and apparent responses of stomata to wind and humidity. Plant Cell Environ. 17:1305-1313.

Josis P, Ndayishimiye V, Rénard C (1983) Étude des relations hydriques chez Coffea arabica L. II. Évaluation de la resistance à la secheresse de divers cultivars à Ghisa (Burundi). Café Cacao Thé 27:275-282.

Kanechi M, Uchida NU, Yasuda T, Yamaguchi T (1995) Water stress effects on leaf transpiration and photosynthesis of Coffea arabica $\mathrm{L}$. under different irradiance conditions. In: Proceedings of the $16^{\text {th }}$ International Scientific Colloquium on Coffee. Association Scientifique Internationale du Café, Paris, pp.520-527.

Maestri M, DaMatta FM, Regazzi AJ, Barros RS (1995) Accumulation of proline and quaternary ammonium compounds in mature leaves of water stressed coffee plants (Coffea arabica and C. canephora). J. Hort. Sci. 70:229-233.

Mazzafera P, Carvalho A (1987) Produção e tolerância à seca de cafeeiros. Bragantia 46:403-415.

Mazzafera P, Teixeira JPF (1989) Prolina em cafeeiros submetidos a déficit hídrico. Turrialba 39:305-313.

Medrano H, Chaves MM, Porqueddu C, Caredda S (1998) Improving forage crops for semi-arid areas. Out. Agric. 27:89-94.

Meguro NE, Magalhães AC (1983) Water stress affecting nitrate reduction and leaf diffusive resistance in Coffea arabica L. cultivars. J. Hort. Sci. 58:147-152.

Meinzer FC, Ingamells JL, Crisosto C (1991) Carbon isotope discrimination correlates with bean yield of diverse coffee seedling populations. HortScience 26:1413-1414.

Meinzer FC, Goldstein G, Grantz DA (1990a) Carbon isotope discrimination in coffee genotypes grown under limited water supply. Plant Physiol. 92:130-135.

Meinzer FC, Grantz DA, Goldstein G, Saliendra NZ (1990b) Leaf water relations and maintenance of gas exchange in coffee cultivars grown in drying soil. Plant Physiol. 94:1781-1787. 
Meinzer FC, Saliendra NZ, Crisosto CH (1992) Carbon isotope discrimination and gas exchange in Coffea arabica during adjustment in different soil moisture regimes. Aust. J. Plant Physiol. 19:171-184.

Mullet JE, Whitsitt MS (1997) Plant cellular responses to water deficit. In: Belhassen E (ed), Drought Tolerance in Higher Plants: Genetical, Physiological and Molecular Biological Analysis, pp.41-46. Kluwer Academic Publishers, Dordrecht, The Netherlands.

Nunes MA (1976) Water relations in coffee: significance of plant water deficits to growth and yield: a review. J. Coffee Res. 6:4-21.

Nunes MA, Duarte NT (1969) Resistência à secura em Coffea arabica - estudo comparativo de duas selecções. Garcia de Orta, Sér. Est. Agron. 17:83-96.

Pinheiro HA (2004) Physiological and morphological adaptations as associated with drought tolerance in robusta coffee (Coffea canephora Pierre var. kouillou). Viçosa, Universidade Federal de Viçosa, PhD Thesis.

Pinheiro HA, DaMatta FM, Chaves ARM, Fontes EPB, Loureiro ME (2004). Drought tolerance as related to protection against oxidative stress in clones of Coffea canephora subjected to long-term drought. Plant Sci., in press.

Ramos RLS, Carvalho A (1997) Shoot and root evaluations on seedlings from Coffea genotypes. Bragantia 56:59-68.

Richards RA (1997) Defining selection criteria to improve yield under drought. In: Belhassen E (ed), Drought Tolerance in Higher Plants: Genetical, Physiological and Molecular Biological Analysis, pp.79-88. Kluwer Academic Publishers, Dordrecht, The Netherlands.

Tausend PC, Goldstein G, Meinzer FC (2000a) Water utilization, plant hydraulic properties and xylem vulnerability in three contrasting coffee (Coffea arabica) cultivars. Tree Physiol. 20:159-168.

Tausend PC, Meinzer FC, Goldstein G (2000b) Control of transpiration in three coffee cultivars: the role of hydraulic and crown architecture. Trees - Struct. Funct. 14:181-190.

Turner NC (1997) Further progress in crop water relations. Adv. Agron. 58:293-338.

Willson KC (1999) Coffee, Cocoa and Tea. CABI Publishing, Cambridge. 